特集(2) 1980 年㻴境行政の今後の課題

\title{
污泥の再資源化の動 向
}

富沢辰治*

\section{1 . 污泥の発生状況}

製造業（電力，がス業を含む）から発生する産業廃 杗物に関する事項だけをピックアップしてみると，表 1のとおりである。これによると污泥の発生量（水分 を含む）は20,158千トンとなっているが, これを生産
金額で換算して全企業の総計を推定すると，昭和 52 年 度で約 3 倍の 62,207 千トンとなっている。

業種別にみると，紙・パルプ工業 $(26 \%)$ ，鉄鋼業 $(20 \%)$, 化学工業 $(18 \%)$, 食料品 $(10 \%)$, 非鉄金

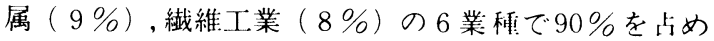
ている。汇泥の発生量原単位についても，これらの業

表 1 業種別活泥発生量と資源化状洸（昭和52年度）

\begin{tabular}{|c|c|c|c|c|c|c|c|c|c|}
\hline 業種コード & $\begin{array}{l}\text { 集計対象 } \\
\text { 工場 数 }\end{array}$ & $\begin{array}{l}\text { 同左生産 } \\
\text { 金額 } \\
\text { (10億円／年) }\end{array}$ & $\begin{array}{l}\text { 同左スラッ } \\
\text { 溌生量 } \\
\text { (千 } \mathrm{t} / \text { 年) }\end{array}$ & $\begin{array}{l}\text { スラッ溌 } \\
\text { 生推計量 } \\
\text { (千 } \mathrm{t} / \text { 年) }\end{array}$ & $\begin{array}{l}\text { スラッジ発 } \\
\text { 生量原単位 } \\
(\mathrm{t} / 10 \text { 億円 })\end{array}$ & $\begin{array}{c}\text { 資源化した } \\
\text { スラッジ量 } \\
(\text { F t } / \text { 年 })\end{array}$ & $\begin{array}{c}\text { 資源化率 } \\
(\%)\end{array}$ & $\begin{array}{l}\text { スラッジ } \\
\text { の処理経 } \\
\text { 費 } \\
(\text { 干円/ } / \mathrm{t})\end{array}$ & $\begin{array}{l}\text { スラッジ } \\
\text { の処分経 } \\
\text { 費 } \\
\text { (千円 / t }\end{array}$ \\
\hline 全 業 種 & 2,643 & $59,272.1$ & 20,158 & 62.207 & 340 & 2,795 & 13.9 & 2.3 & 2.6 \\
\hline 18,19 食料品 & 175 & $2,500.2$ & 2,036 & 14,916 & 814 & 22 & 1.1 & 1.8 & 4.4 \\
\hline 20 械 維 工業 & 193 & $1,887.0$ & 1,546 & 5,655 & 819 & 1 & 0.1 & 0.4 & 4.5 \\
\hline $21 "$ 製品 & 31 & 98.0 & 144 & 364 & 1.469 & - & - & 0.2 & 4.9 \\
\hline 22 木 製 品 & 26 & 149.3 & 6 & 17 & 40 & - & 3.5 & 7.7 & 6.9 \\
\hline 23 家具·装備 & 20 & 67.3 & 8 & 25 & 119 & - & - & 1.5 & 8.5 \\
\hline 24 紙・バルプ & 106 & $1,672.7$ & 5,238 & 15.730 & 3,131 & 270 & 5.2 & 1.7 & 2.3 \\
\hline 25 出版 & 51 & 1.592 .5 & 6 & 18 & 4 & - & 0.4 & 11.7 & 29.1 \\
\hline 26 化学工業 & 360 & $6,241.5$ & 3,536 & 7,072 & 567 & 981 & 27.7 & 3.3 & 3.2 \\
\hline 27 石油 - 石炭 & 40 & 5.981 .3 & 254 & 377 & 42 & 65 & $25.5^{\prime}$ & 10.9 & 8.9 \\
\hline 28 ゴム製品 & 58 & 656.7 & 2 & 5 & 3 & - & 18.2 & 3.3 & 9.8 \\
\hline 29 皮 製 品 & 12 & 40.2 & 38 & 742 & 945 & - & 0.2 & 3.2 & 5.8 \\
\hline 30 窯 業 & 124 & $1,143.0$ & 272 & 1,357 & 238 & 73 & 26.7 & 1.5 & 1.9 \\
\hline 31 鉄 鋼 & 160 & $7,705.3$ & 3,978 & 6,769 & 516 & 734 & 18.5 & 3.1 & 2.3 \\
\hline 32 非鉄金属 & 98 & $2,195.3$ & 1,824 & 4,366 & 831 & 52 & 2.8 & 1.6 & 1.4 \\
\hline 33 金属裴品 & 106 & $1,327.1$ & 620 & 3,563 & 467 & 560 & 90.2 & 4.9 & 4.7 \\
\hline 34 機械器具 & 239 & $5,404.6$ & 114 & 265 & 21 & - & 0.3 & 3.8 & 8.1 \\
\hline 35 電気機 器 & 356 & 5.655 .5 & 68 & 180 & 12 & 3 & 3.9 & 4.7 & 10.3 \\
\hline 36 輸送機械 & 233 & $9,906.9$ & 292 & 553 & 29 & 2 & 0.6 & 5.5 & 6.3 \\
\hline 37 精 密 機 器 & 67 & 982.2 & 7 & 17 & 7 & - & 0.2 & 19.0 & 12.8 \\
\hline 39 その他製造 & 52 & 429.1 & 23 & 34 & 54 & - & 0.1 & 4.4 & 10.3 \\
\hline 41 古紙再生 & - & - & - & - & - & - & - & - & - \\
\hline 70 電 力 & 73 & $※ 309,000$ & 125 & 148 & - & 29 & 21.8 & 9.7 & 20.5 \\
\hline 71 ガ ス 業 & 61 & 511.1 & 21 & 34 & 41 & 3 & 16.2 & 12.0 & 5.6 \\
\hline
\end{tabular}

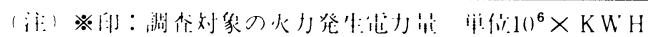


種が多いことが示されている.

また, 昭和50年度に通商産業者が実施した昭和 49 年 度の污泥の種類別発生状況, 再資源化状況を調べた結 果によると, 污泥の種類別発生比率は図ー1のとおり であり, 発生量, 処分量は表 2 のとおりである。種類

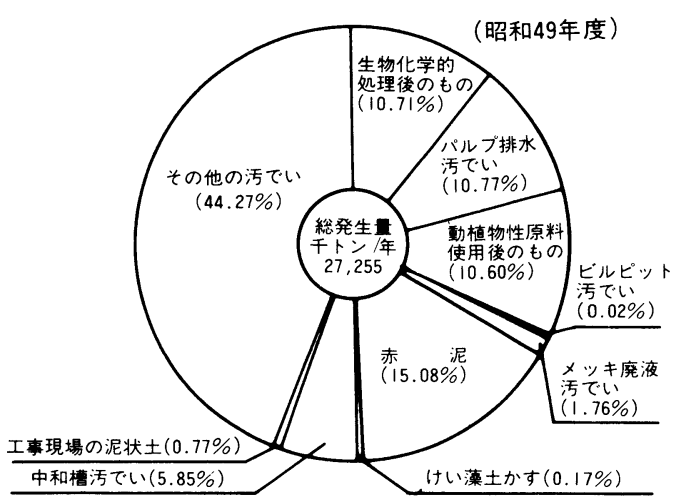

図一 1 污泥の発生状況

表 2 污泥の種類別処分状況表(昭和49年度)

$(1,000 \mathrm{t} /$ 年 $)$

\begin{tabular}{|c|c|c|c|c|c|c|}
\hline \multirow[b]{2}{*}{ 璉類 } & \multicolumn{2}{|c|}{ 自社处分 } & \multicolumn{2}{|c|}{ 委託处分 } & \multicolumn{2}{|c|}{ 合 計 } \\
\hline & 量 & $\%$ & 量 & $\%$ & 量 & $\%$ \\
\hline $\begin{array}{l}\text { 生物化学的処理 } \\
\text { 後のもの }\end{array}$ & 1,464 & 52.70 & 1,314 & 47.30 & 2,778 & 100.00 \\
\hline バルプ排水污泥 & 940 & 30.96 & 2,096 & 69.04 & 3,036 & 100.00 \\
\hline $\begin{array}{l}\text { 動值物性原料使 } \\
\text { 用のもの }\end{array}$ & 2,234 & 81.62 & 503 & 18.38 & 2,737 & 100.00 \\
\hline ビルピット污泥 & 0 & 0 & 4 & 100 & 4 & 100.00 \\
\hline メッキ廃液污泥 & 102 & 20.86 & 387 & 79.14 & 489 & 100.00 \\
\hline 本 & 2,247 & 52.81 & 2,008 & 47.19 & 4,255 & 100.00 \\
\hline けい藻土か寸 & 12 & 27.27 & 32 & 72.73 & 44 & 100.00 \\
\hline 中和 槽污泥 & 974 & 62.04 & 596 & 37.96 & 1,570 & 100.00 \\
\hline $\begin{array}{l}\text { 工事現場の混状 } \\
\text { 土 }\end{array}$ & 180 & 83.33 & 36 & 16.67 & 216 & 100.00 \\
\hline そ の 他 & 7,287 & 60.10 & 4,838 & 39.90 & 12,125 & 100.00 \\
\hline 合計 & 15,440 & 56.65 & 11,815 & 43.35 & 27,255 & 1000.0 \\
\hline
\end{tabular}

別にみると赤泥 $(15 \%)$ ，パルプ排水污泥(10.8\%)， 生物化学的処理後のもの $(10.7 \%)$, 動植物性原料使用
後のもの $(10.6 \%)$ が多い.

発生源別には排水処理工程から発生するものが $54 \%$, 生産工程から発生するものが $41 \%$ その他が $5 \%$ となっ ている。

\section{2 . 污泥の発生状況の推移}

污泥の発生状況等の推移を過去のデータより比較し てみると, 污泥排出量については表 3 のとおりとなる。

表 3 污泥排出量年度比較表（48年度，52年度）

単位：千トン/年

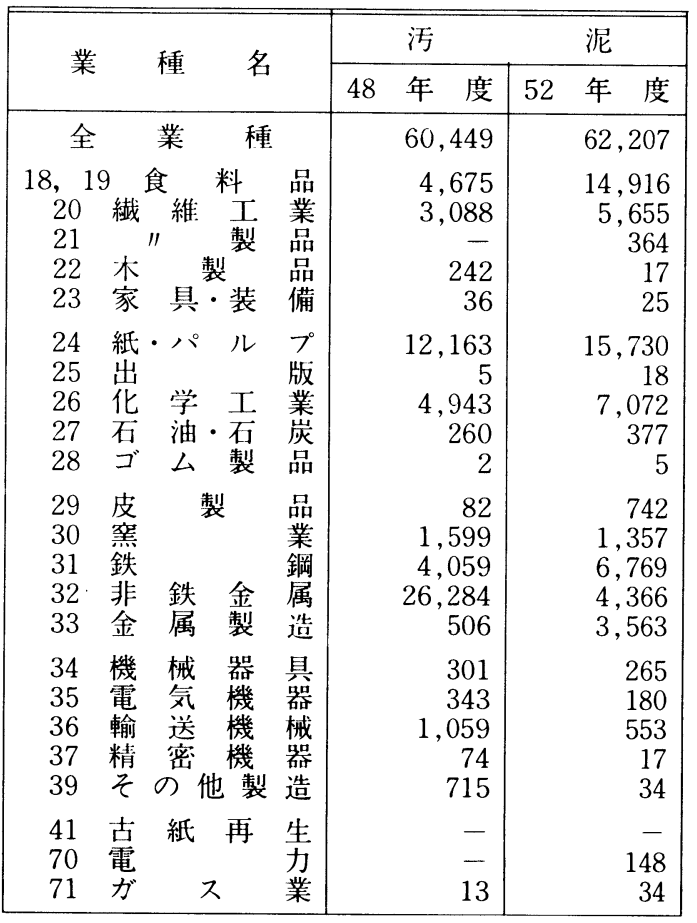

排出量総量については，48年度と比較し 52年度は顕著 な変化はみられないが各業種排出量においては、増減 がみられる。例之ば，52年度産業廃棄物排出量原単位 調査結果では，48年度同調查と比較して，食料品（10 ,241千トン増), 繊維工業 $(2,567$ 千トン増), 紙・八゚ ルプ (3,567千トン増), 化学工業 $(2,129$ 千トン増), 非鉄金属 $(21,918$ 千トン減), 金属製品製造業(3,057千 トン増）となっている。

污泥排出原単位年度比較, 污泥資源化率年度比較に ついて表 4, 表 5 に示す. 原単位については, 生産金 額10億円当り 48年度 613 トンが52年度では340 トンに 減少している。資源化率については，48年度3.0\%が 52 年度 $13.9 \%$ となっており, 污泥についても他の産業 
表 4 污泥排出原単位年度比較表 (48年度, 52 年度)

（トン／10億円）

\begin{tabular}{|c|c|c|c|c|c|c|c|}
\hline \multirow{2}{*}{ 業 } & & \multirow{2}{*}{\multicolumn{2}{|c|}{ 名 }} & \multicolumn{2}{|r|}{ 污 } & \multicolumn{2}{|r|}{ 泥 } \\
\hline & & & & 48 & 度 & 52 & 年 \\
\hline 全 & & 種 & & & 613 & & 340 \\
\hline 18 & & 食＜wide>料 & 品 & & 471 & & 814 \\
\hline 20 & 繊 & 維 I & 業 & & 512 & & 819 \\
\hline 21 & & $" \prime$ 製 & 品 & & 4 & & 1,469 \\
\hline 22 & 木 & 製 & 品 & & 85 & & 40 \\
\hline 23 & 家 & 具・装 & 備 & & 21 & & 119 \\
\hline 24 & 紙 & •パ ル & $7^{\circ}$ & & 3,571 & & 3,131 \\
\hline 25 & 出 & & 版 & & 2 & & 4 \\
\hline 26 & 化 & 学 工 & 業 & & 664 & & 567 \\
\hline 27 & 石 & 油・石 & 炭 & & 86 & & 42 \\
\hline 28 & ゴ & 么 製 & 品 & & 3 & & 3 \\
\hline 29 & 皮 & 製 & 品 & & 259 & & 945 \\
\hline 30 & 窯 & & 業 & & 448 & & 238 \\
\hline 31 & 鉄 & & 鋼 & & 445 & & 516 \\
\hline 32 & 非 & 鉄 金 & 属 & & 5,953 & & 831 \\
\hline 33 & 金 & 属 製 & 品 & & 100 & & 467 \\
\hline 34 & 機 & 械器 & 具 & & 33 & & 21 \\
\hline 35 & 電 & 機 & 器 & & 32 & & 12 \\
\hline 36 & 輸 & 送 & 械 & & 93 & & 29 \\
\hline 37 & 精 & 密＼cjkstart機 & 器 & & 51 & & 7 \\
\hline 39 & そ & の 他 製 & 造 & & 194 & & 54 \\
\hline 41 & 古 & 紙＼cjkstart再 & 生 & & - & & - \\
\hline 70 & 電 & & 力 & & 3 & & - \\
\hline 71 & ガ & x & 業 & & 38 & & 41 \\
\hline
\end{tabular}

廃棄物と同様に徐々に再資源化の高まりをみせている。

活泥処理経費年度比較, 污泥処分経費年度比較につ いては，表 6, 䘚 7 に示す。処理経費はトン当り平均

表 6 污泥処理経費年度比較表（48年度，52年度） （トン当り平均）

(千円／トン )

\begin{tabular}{|c|c|c|c|c|c|c|c|}
\hline \multirow{2}{*}{\multicolumn{2}{|c|}{ 業 }} & \multirow{2}{*}{ 種 } & \multirow{2}{*}{ 名 } & \multicolumn{2}{|r|}{ 污 } & \multicolumn{2}{|r|}{ 泥 } \\
\hline & & & & 48 & 年 度 & 52 & 年 \\
\hline 全 & & 種 & & & 31.8 & & 2.3 \\
\hline $18, \quad 19$ & & 食 料 & 品 & & 38.5 & & 1.8 \\
\hline 20 & 繊 & 維 工 & 業 & & 7.6 & & 0.4 \\
\hline 21 & & 製 & 品 & & 1.2 & & 0.2 \\
\hline 22 & 木 & 製 & 品 & & 7.4 & & 7.7 \\
\hline 23 & 家 & 具・装 & 備 & & 14.0 & & 1.5 \\
\hline 24 & 紙 & ・パ & プ & & 9.2 & & 1.7 \\
\hline 25 & 出 & & 版 & & 116.7 & & 11.7 \\
\hline 26 & 化 & 学 工 & 業 & & 20.9 & & 3.3 \\
\hline 27 & 石 & 油・石 & 炭 & & 76.8 & & 10.9 \\
\hline 28 & ゴ & 么 製 & 品 & & 84.9 & & 3.3 \\
\hline 29 & 皮 & 製 & 品 & & 9.8 & & 3.2 \\
\hline 30 & 窯 & & 業 & & 11.0 & & 1.5 \\
\hline 31 & 鉄 & & 鋼 & & 11.0 & & 3.1 \\
\hline 32 & 非 & 鉄 & 属 & & 87.9 & & 1.6 \\
\hline 33 & 金 & 属製 & 品 & & 19.7 & & 4.9 \\
\hline 34 & 機 & 械 器 & 具 & & 50.3 & & 3.8 \\
\hline 35 & 電 & 気 機 & 器 & & 53.8 & & 4.7 \\
\hline 36 & 輸 & 送 機 & 械 & & 19.3 & & 5.5 \\
\hline 37 . & 精 & 密 機 & 器 & & 54.2 & & 19.0 \\
\hline 39 & そ & の他 製 & 造 & & 39.7 & & 4.4 \\
\hline 41 & 古 & 紙＼cjkstart再 & 生 & & - & & - \\
\hline 70 & 電 & & 力 & & 90.3 & & 9.7 \\
\hline 71 & ガ & ス & 業 & & 68.4 & & 12.0 \\
\hline
\end{tabular}

表 5 污泥資源化率年度比較 (48年度, 52 年度)

$(\%)$

\begin{tabular}{|c|c|c|c|c|c|c|c|}
\hline \multirow{2}{*}{ 業 } & \multirow{2}{*}{ 柇 } & \multirow{2}{*}{\multicolumn{2}{|c|}{ 名 }} & \multicolumn{3}{|c|}{ 污 } & 泥 \\
\hline & & & & 48 & 年 度 & 52 & 年 \\
\hline 全 & & 種 & & & 3.0 & & 13.9 \\
\hline 18,1 & & 食＼cjkstart料 & 品 & & 4.4 & & 1.1 \\
\hline 20 & 繊 & 維 I & 業 & & - & & 0.1 \\
\hline 21 & & 製 & 品 & & - & & - \\
\hline 22 & 木 & 製 & 品 & & - & & 3.5 \\
\hline 23 & 家 & 具・装 & 備 & & - & & - \\
\hline 24 & 紙 · & ・パ ル & プ & & 1.3 & & 5.2 \\
\hline 25 & 出 & & 版 & & - & & 0.4 \\
\hline 26 & 化 & 学: 工 & 業 & & - & & 27.7 \\
\hline 27 & 石 & 油 - 石 & 炭 & & 2.8 & & 25.5 \\
\hline 28 & ゴ & 么 製 & 品 & & - & & 18.2 \\
\hline 29 & 皮 & 製 & 品 & & - & & 0.2 \\
\hline 30 & 点 & & 業 & & 3.1 & & 26.7 \\
\hline 31 & 鉄 & & 銅 & & 17.4 & & 18.5 \\
\hline 32 & 非 & 鉄 金 & 属 & & 0.9 & & 2.8 \\
\hline 33 & 金 & 属 製 & 品 & & 0.6 & & 90.2 \\
\hline 34 & 機 & 械 器 & 具 & & 0.1 & & 0.3 \\
\hline 35 & 電 & 父 機 & 器 & & 1.2 & & 3.9 \\
\hline 36 & 輸 & 送 機 & 械 & & - & & 0.6 \\
\hline 37 & 精 & 密＼cjkstart機 & 器 & & - & & 0.2 \\
\hline 39 & 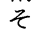 & の，他 製 & 造 & & - & & 0.1 \\
\hline 41 & 古 & 紙＼cjkstart再 & 生 & & - & & - \\
\hline 70 & 電 & & 力 & & - & & 22.8 \\
\hline 71 & ガ & x & 業 & & 8.3 & & 16.2 \\
\hline
\end{tabular}

48年度31.8千円／トンより52年度2.3千円/トンとなり, 処分経費についてもトン当り平均48年度11.4千円／卜 ンより52年度は，2.6千円／トンとなっている。

表 7 污泥処分経費年度比較表(48年度，52年度） (トン当り平均)

(千円 /トン)

\begin{tabular}{|c|c|c|c|c|c|c|c|c|}
\hline \multirow{2}{*}{ 業 } & \multirow{2}{*}{ 種 } & \multirow{2}{*}{\multicolumn{2}{|c|}{ 名 }} & \multicolumn{3}{|c|}{ 污 } & \multicolumn{2}{|l|}{ 泥 } \\
\hline & & & & 48 & 年 度 & 52 & 年 & 度 \\
\hline 全 & & 種 & & & 11.4 & & & 2.6 \\
\hline 18,1 & & 料 & 品 & & 5.5 & & & 4.4 \\
\hline 20 & 繊 & 維 工 & 業 & & 7.1 & & & 4.5 \\
\hline 21 & & " 製 & 品 & & 8.5 & & & 4.9 \\
\hline 22 & 木 & 製 & 品 & & 4.8 & & & 6.9 \\
\hline 23 & 家 & 具·装 & 備 & & 12.3 & & & 8.5 \\
\hline 24 & 紙 & ・パ ル & プ & & 2.0 & & & 2.3 \\
\hline 25 & 出 & & 版 & & 72.8 & & & 9.1 \\
\hline 26 & 化 & 学 工 & 業 & & 9.7 & & & 3.2 \\
\hline 27 & 石 & 油・石 & 炭 & & 5.7 & & & 8.9 \\
\hline 28 & ゴ & 么 製 & 品 & & 10.1 & & & 9.8 \\
\hline 29 & 皮 & 製 & 品 & & 6.4 & & & 5.8 \\
\hline 30 & 窵 & & 業 & & 6.3 & & & 1.9 \\
\hline 31 & 鉄 & & 鋼 & & 6.8 & & & 2.3 \\
\hline 32 & 非 & 金 & 属 & & 13.5 & & & 1.4 \\
\hline 33 & 金 & 属 製 & 品 & & 9.7 & & & 4.7 \\
\hline 34 & 機 & 械 器 & 具 & & 24.6 & & & 8.1 \\
\hline 35 & 電 & 気 & 器 & & 15.8 & & & 0.3 \\
\hline 36 & 輸 & 送 & 械 & & 12.3 & & & 6.3 \\
\hline 37 & 精 & 密＼cjkstart機 & 器 & & 26.1 & & & 2.8 \\
\hline 39 & そ & の 他 製 & 造 & & 12.7 & & & 0.3 \\
\hline 41 & 古 & 紙＼cjkstart再 & 生 & & - & & & - \\
\hline 70 & 電 & & 力 & & 9.2 & & & 0.5 \\
\hline 71 & ガ & ス & 業 & & 2.9 & & & 5.6 \\
\hline
\end{tabular}




\section{3 . 污泥の再資源化}

污泥の再資源化の現状を業種別にみると, 表 1 に示 すとおりであり，資源化比率は全体で13.9\%程度で, 廃棄物全体の $48.6 \%$ に比較して著しく低いことがわか る.

污泥の種類別にみると, 昭和50年度に実施した昭和 49年度の前記調査結果によると, 再資源化状況は表 8 のとおりである。

さらに昭和 $51 ， 52$ 年度にわたって通商産業省におい て，業種別に再利用されている廃充物の実態を調査し， 各種の污泥の発生工程, 再利用方法, 利用率等につい て調査した。それを種類別に用途区分すると表 9 のと おりとなる。

この表でも明らかなように，有機性污泥の飼料，肥 料，その他の原料として使用される場合が多く，含有 金属污泥は山元還元等金属の回収に利用され，その他 の無機性污泥は骨材等建設材料として利用される場合 が多い.

污泥の再資源化の技術としては, 次の方法が開発ま
たは奉用化されている。

無機性污泥については, (1)セメントその他の薬剤に より固化する方式, (2)プラスチックを用いて固化する 方式，(3)粘土等を混合して酸化焼成固化する方式，(4) 重金属含有污泥の還元焼成による固化方式, 金属含有 污泥の山元還元等による金属の回収方式, (5)その他, がある。

無機性污泥については, (1)乾燥, コンポスト化等に より肥料または土壤改良剤として利用する方式，(2)熱 分解により燃料化する方式, (3)燃焼して熱エネルギー として利用する方式, (4)メタン発酵による有価ガスの 回収方式，(5)その他の方式がある。

\section{4. 資源化の問題点と解決の方向}

污泥の資源化再利用については, 最近各種の技術が 開発され，実用化段階に至っているものもあるが，経 済性等の問題点が大きく，実際に利用されている例は 非常に少ない.

その原因としては，次のような問題点や対策がある.

表 8 污泥の再利用状況一覧表（昭和49年度）

（上段：実数(千トン） 下段：割合 $(\%)$ )

\begin{tabular}{|c|c|c|c|c|c|c|c|c|c|c|}
\hline 污泥の種類 & $\begin{array}{ll}\text { 肥 } & \text { 料 } \\
\text { 飼 料 }\end{array}$ & 燃 料 & 建 材 & $\begin{array}{c}\text { 土壤改 } \\
\text { 材 }\end{array}$ & $\begin{array}{l}\text { セメン } \\
\text { ト原料 }\end{array}$ & 骨 材 & 金属回収 & $\begin{array}{l}\text { 原料とし } \\
\text { て利用 }\end{array}$ & $\begin{array}{l}\text { 不明 } \\
\text { その他 }\end{array}$ & 合 計 \\
\hline $\begin{array}{l}\text { 生物化学的処理後 } \\
\text { のもの }\end{array}$ & $\begin{array}{r}724 \\
90.04\end{array}$ & & & & & $\begin{array}{r}19 \\
2.36\end{array}$ & & $\begin{array}{r}61 \\
7.59\end{array}$ & & $\begin{array}{r}804 \\
100.00\end{array}$ \\
\hline パルプ排水污泥 & $\begin{array}{r}5 \\
11.90\end{array}$ & & $\begin{array}{r}3 \\
7.14\end{array}$ & & & & & & $\begin{array}{r}34 \\
80.95\end{array}$ & $\begin{array}{r}42 \\
100.00\end{array}$ \\
\hline $\begin{array}{l}\text { 動植物性原料使用 } \\
\text { 後のもの }\end{array}$ & $\begin{array}{r}614 \\
25.22\end{array}$ & & & & & & & $\begin{array}{l}1,820 \\
74.74\end{array}$ & $\begin{array}{r}1 \\
0.04\end{array}$ & $\begin{array}{r}2,435 \\
100.00\end{array}$ \\
\hline ビルピット污泥 & & & & & & & & & & $\begin{array}{l}- \\
-\end{array}$ \\
\hline メッキ廃液污泥 & & & & & & & $\begin{array}{r}203 \\
99.51\end{array}$ & $\begin{array}{r}1 \\
0.49\end{array}$ & & $\begin{array}{r}204 \\
100.00\end{array}$ \\
\hline 赤 & & & & & $\begin{array}{r}4 \\
100.00\end{array}$ & & & & & $\begin{array}{r}4 \\
100.00\end{array}$ \\
\hline けい藻土かす & & & & & & & & & & - \\
\hline 中和槽污でい & & & & $\begin{array}{r}1 \\
10.5\end{array}$ & $\begin{array}{r}7 \\
7.37\end{array}$ & $\begin{array}{r}23 \\
24.21\end{array}$ & $\begin{array}{r}1 \\
1.05\end{array}$ & $\begin{array}{r}49 \\
51.58\end{array}$ & $\begin{array}{r}14 \\
14.74\end{array}$ & $\begin{array}{r}95 \\
100.00\end{array}$ \\
\hline 工事現場の泥状土 & & & & & & & & & & - \\
\hline の & $\begin{array}{r}134 \\
2.69\end{array}$ & $\begin{array}{r}2 \\
0.04\end{array}$ & $\begin{array}{r}156 \\
3.13\end{array}$ & $\begin{array}{l}1,605 \\
32.22\end{array}$ & $\begin{array}{r}525 \\
10.54\end{array}$ & & $\begin{array}{r}23 \\
0.46\end{array}$ & $\begin{array}{l}2,348 \\
47.13\end{array}$ & $\begin{array}{r}189 \\
3.79\end{array}$ & $\begin{array}{r}4,982 \\
100.00\end{array}$ \\
\hline 合 & $\begin{array}{l}1,477 \\
17.24\end{array}$ & $\begin{array}{r}2 \\
0.02\end{array}$ & $\begin{array}{r}159 \\
1.86\end{array}$ & $\begin{array}{l}1,606 \\
18.75\end{array}$ & $\begin{array}{r}536 \\
6.26\end{array}$ & $\begin{array}{r}42 \\
0.49\end{array}$ & $\begin{array}{r}227 \\
2.65\end{array}$ & $\begin{array}{l}4,278 \\
49.95\end{array}$ & $\begin{array}{r}238 \\
2.78\end{array}$ & $\begin{array}{r}8,565 \\
100.00\end{array}$ \\
\hline
\end{tabular}


表 9 污泥の名称別利用状況例(1)

\begin{tabular}{|c|c|c|c|c|c|c|c|c|c|c|c|c|}
\hline \multirow{2}{*}{$\begin{array}{l}\text { 廃棄 } \\
\text { 物の } \\
\text { 種類 }\end{array}$} & \multirow[b]{2}{*}{ 名 称 } & \multirow{2}{*}{$\begin{array}{l}\text { 同種のも } \\
\text { のに再生 }\end{array}$} & \multicolumn{2}{|c|}{ 工 業 原 料 } & \multirow{2}{*}{$\begin{array}{l}\text { 中和剂 } \\
\text { 等薬剂 }\end{array}$} & \multirow{2}{*}{ 燃料 } & \multirow{2}{*}{ 肥 料 } & \multirow{2}{*}{$\begin{array}{l}\text { 土壤 } \\
\text { 改良郕 }\end{array}$} & \multirow{2}{*}{ 飼 料 } & \multirow{2}{*}{$\begin{array}{l}\text { 建設 } \\
\text { 材料 }\end{array}$} & \multirow{2}{*}{$\begin{array}{l}\text { その } \\
\text { 他 }\end{array}$} & \multirow{2}{*}{$\begin{array}{l}\text { 業種番号 } \\
\text { (中分類) }\end{array}$} \\
\hline & & & 金属回収 & その他 & & & & & & & & \\
\hline 污泥 & 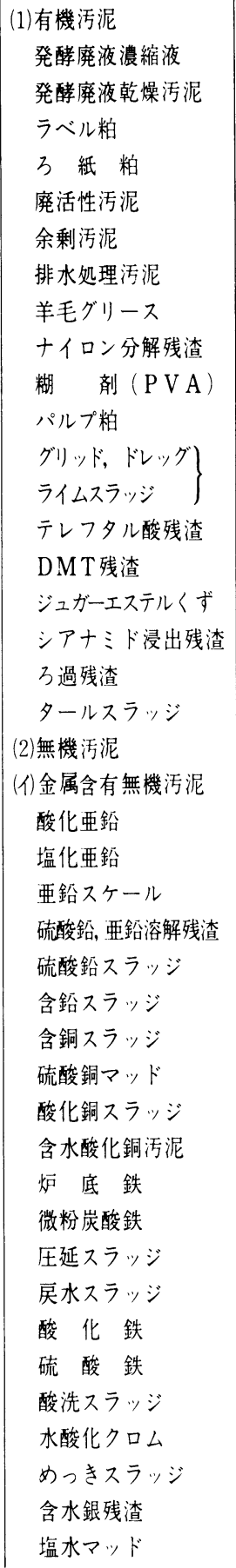 & $\mathrm{OB} \cdot \mathrm{C}$ & $\begin{array}{l} \\
\mathrm{OA} \cdot \mathrm{C} \\
\mathrm{A} \cdot \mathrm{B} \\
\mathrm{OB} \\
\mathrm{OA} \cdot \mathrm{B} \cdot \mathrm{C} \\
\mathrm{A}\end{array}$ & $\begin{array}{l}O \mathrm{~B} \\
\mathrm{OB} \\
\mathrm{OA} \cdot \mathrm{B} \cdot \mathrm{C} \\
\mathrm{OB} \\
\mathrm{OA} \\
\mathrm{OA} \cdot \mathrm{C} \\
\mathrm{OA} \cdot \mathrm{B} \\
\\
\mathrm{OC} \\
\mathrm{OA} \\
\mathrm{OC} \\
\mathrm{OA} \\
\mathrm{OA} \\
\mathrm{OA} \\
\mathrm{OA} \\
\mathrm{OA} \\
\mathrm{OA} \\
\end{array}$ & $\begin{array}{l}O A \\
O A\end{array}$ & & $\begin{array}{l}O A \cdot B \\
O B \\
O A \cdot B \cdot C \\
O A \cdot B \\
O A \cdot B\end{array}$ & $\mathrm{OA} \cdot \mathrm{B}$ & $\mathrm{OA} \cdot \mathrm{B}$ & $\mathrm{OB}$ & $O B$ & 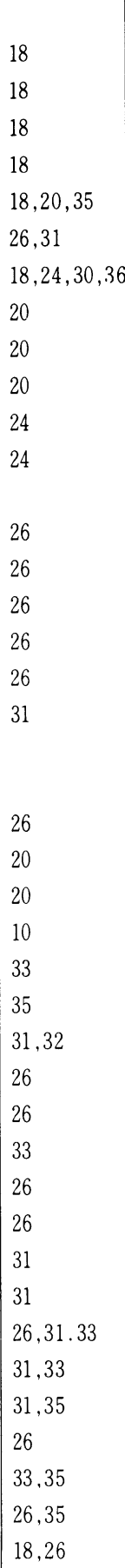 \\
\hline
\end{tabular}


表 9 污泥の名称別利用状況例(2)

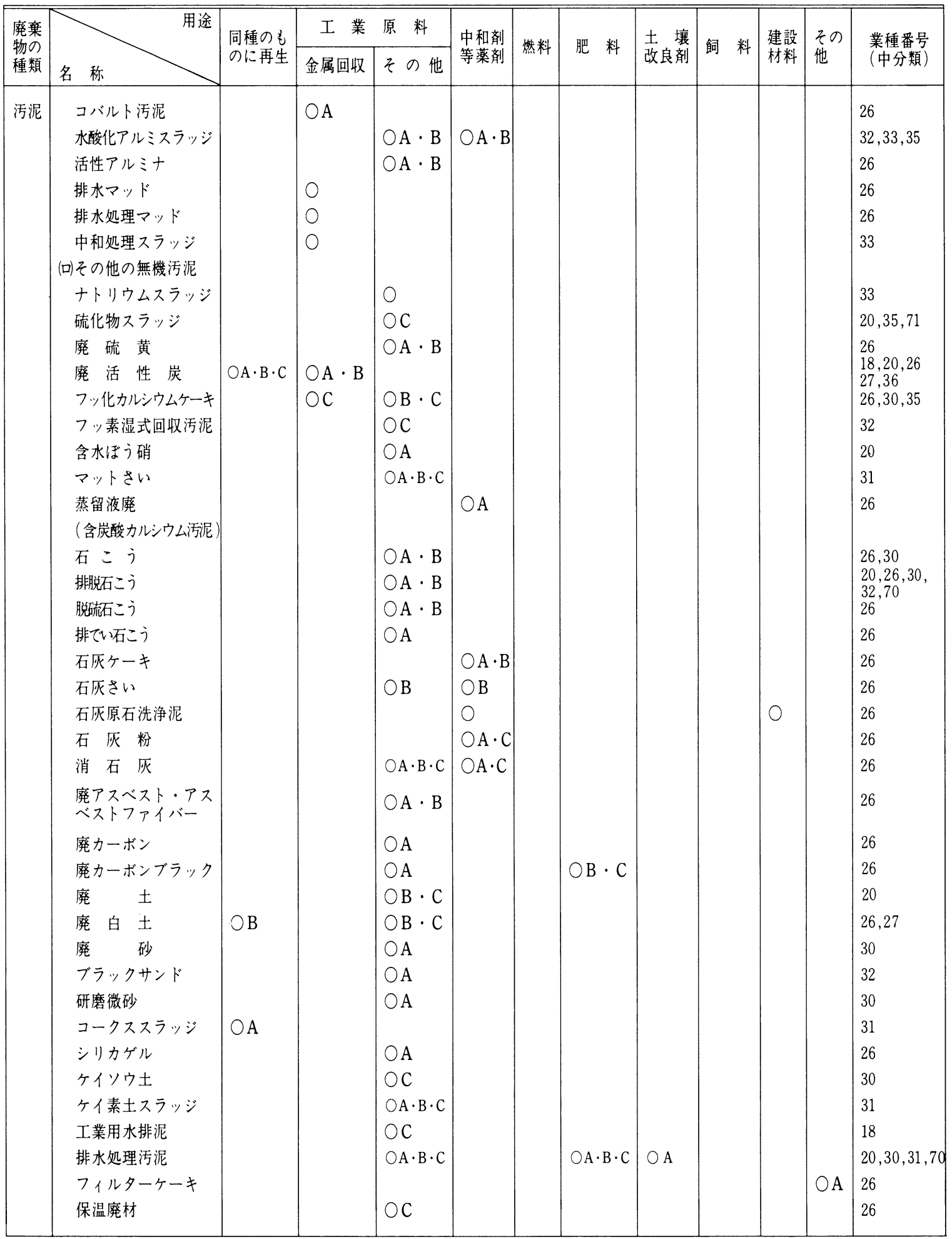




\section{（1）回収体制の整備}

資源化を効率的に行うには, 同質の污泥を相当程度 の量をまとまって回収することが必要である。このた め，排出側でも分別して排出するとともに，これらを 効率的に回収，運搬するシステムを確立しなければな らない。

\section{（2）有害金属を含む污泥の利用}

有害物質，特に重金属を含む污泥等はその取扱いが 法的に制約を受けているが，将来は含有金属の回収を 処理の最重点に考慮すべきであり，現在行われている 山元還元等をさらに効率的に推進すべきである。この ためこれに対する助成方策等も考えるべきである。

\section{(3) 技術開発の促進}

污泥の再資源化に関する技術開発は相当行われてい るが，未開発の分野も非常に多い。また，開発された 技術が実用化されるためのモデル実験技術開発を確立 していかなければならない.

このため，国，地方公共団体等の技術開発に関する 援助措置を強化する必要がある。

\section{(4) エ場内リサイクルの促進}

污泥はできるだけ自工場内でリサイクルして利用す
ることが望ましい，このため，工場内で利用すること を再検討するとともに, 利用している事例の普及, 助 成措置の強化等が望まれる。

\section{（5）再資源化業者の育成}

污泥を再資源化する企業はまだ極めて少なく，かつ規 模も小さいため非能率であることが多い。このためそ れらの業者の育成のため, 指導, 助成措置の強化を図 る必要がある。

また，共同化，協業化等の方策も推進する必要があ る.

\section{（6）再資源化製品の市場開拓}

污泥から再資源化した製品, 例之ば肥料, 土壤改良 剂，建設資材，燃料等の利用範囲が限られている。こ のため, これらの市場を開拓するとともに，品質の統 一，販路の安全等の対策も必要である。

\section{(7) 関係法令の運用等}

再資源化を促進するため, 先般廃棄物処理法の運用 を改正し, 広域輸送の簡素化, もっぱら再生利用の目 的となる廃棄物の取り扱いの改正等資源化, 再生利用 の促進を図ることとしたが，さらに再資源化促進のた めの新たな法制度の制定についても検討する必要があ る. 